International Review of Public Policy

1:2| 2019

Regular Issue

\title{
Dynamic narrative: a new framework for policy
} success

\section{Germana Nicklin}

\section{(2) OpenEdition \\ 1 Journals}

Electronic version

URL: http://journals.openedition.org/irpp/550

ISSN: 2706-6274

\section{Publisher}

International Public Policy Association

Printed version

Date of publication: 10 October 2019

Number of pages: 173-193

ISSN: 2679-3873

\section{Electronic reference}

Germana Nicklin, «Dynamic narrative: a new framework for policy success », International Review of Public Policy [Online], 1:2 | 2019, Online since 10 December 2019, connection on 05 January 2020.

URL : http://journals.openedition.org/irpp/550

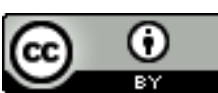

International Review of Public Policy is licensed under a Creative Commons Attribution 4.0 International. 


\section{Dynamic narrative: a new framework for policy success}

\section{Germana Nicklin}

Senior Lecturer and Deputy Director, Centre for Defence and Security Studies, Massey University, New Zealand

\section{Abstract}

This article proposes a new framework for policy success that potentially facilitates planning, tracking, evaluating and communicating the trajectory of successes in a policy initiative. In this reframing of success, rather than being singular, successes are multiple and relational. Playing out in a shifting story-scape that progresses throughout the life of a policy, this approach addresses many of the challenges for public administrators trying to establish policy success in a demanding and complex policy environment. Re-purposing data from research on a transnational border policy development over 2009 to 2012, this article applies the new framework to illustrate the power of the new approach. Using concepts of relationality, multiplicity, translation and stabilization, it builds on and acknowledges the value of Marsh and McConnell's framework for policy success. This dynamic narrative approach blends the narrative contributions of Hannah Arendt and Bruno Latour with Marsh and McConnell's three dimensions of success. In so doing, it reveals the effects of shifting narratives across the three dimensions, and demonstrates how it addresses problems with Marsh and McConnell's framework. Its ability to be forward-looking, and therefore valuable for planning, differentiates the approach from criticisms of the retroactive, and therefore limited use, of other policy narrative approaches.

\section{Keywords}

policy success, multiplicity, policy narrative, translation, actor-network theory, trans-Tasman 


\section{Introduction}

For government officials, establishing the success of policies has long been problematic. For example, what a politician may see, or claim, as success may have significant implementation problems; conversely, a policy evaluated as successful within the public sector may seem ineffectual to politicians and citizens. Indeed, Bovens et al. encapsulate the problem in their statement: "Success and failure mean different things to different people at different times (Bovens, T'Hart, \& Peters, 2001, p. 20). For public administrators (by which we mean non-elected and non-partisan public or civil servants), understanding policy success better and having tools to increase the chances of not only achieving success but also managing the disruptive effects of media and political depictions of success and failure, is important in several ways. First, public administrators need to be able to track the trajectory of success during development and implementation so they can learn what worked and why. Second, they need to be able to communicate that trajectory effectively to interested parties. Third, they need the political space or a form of authorizing environment to review initiatives and apply what they learned to new situations.

One of the difficulties has been factoring the diverse elements of success into an explanatory framework that can bring both structure and insight to assessing whether a policy is successful or not. Bovens et al.(2001) have conducted the most extensive research on the topic to date, in which they identified two dimensions of success - political and programmatic. Marsh and McConnell expanded and developed this concept into a three dimensional framework that includes more criteria for assessment (Marsh \& McConnell, 2010a, 2010b). They argue that empirical research must "explore the tensions and contradictions" between the three dimensions (Marsh \& McConnell, 2010a, p. 581). More recently, Van Assche, Beunen, \& Duineveld, (2012) addressed the effects of the performativity of success and failure in governance.

Welcome as they are, none of these developments adequately address the day-to-day challenges encountered by practitioners operating in a dynamic, demanding and complex policy environment. While promising, Marsh and McConnell's framework, lacks an engine that has the explanatory power to illuminate and mitigate some of the uncertainties in the development and implementation of public policy. The following analysis seeks to address this gap by arguing for a new framework that treats policy success and the stories of policy success as dynamic, progressive, relational and multiple. This new approach will enable proactive planning with the potential to provide more transparency over when and how success is claimed.

This proposition is illustrated through an empirical study set in a cross-jurisdictional border management policy environment at the nexus of competing economic and security political interests between Australia and New Zealand from 2009 to 2012. The challenges of this nexus are familiar to many countries with contiguous borders. This study reveals the challenges of countries with non-contiguous borders and is timely because it may allow us to measure the outcomes of the United Kingdom's exit negotiations with the European Union. Moreover, the relationship between Australia and New Zealand has been compared to that between the United States and Canada, albeit on a larger scale.

The study demonstrates the analytical power of the new framework against actions taken by border management officials from New Zealand and Australia. Using four new elements from the work of Hannah Arendt and Bruno Latour - relational effects, multiplicity, translation and stabilization - it addresses the inherent problems and gaps in Marsh and McConnell's policy success framework. After outlining the methodology and setting the scene for the empirical 
study, the new framework is applied to the data. This process reveals two key generalizable insights that provide a proactive application of the dynamic narrative approach: First, rather than success being an end-point, the life of a policy contains a multiplicity of successes that can be tracked and measured. Second, deep webs of relations, many originating before the start of the policy, drive through and around the dimensions of success through multiple, shifting narratives. These webs affect the ways in which success is tracked and measured.

These insights reframe policy success as relative and multiple. Such reframing will enable the planning and monitoring of successes throughout policy initiatives and provide much-needed space and flexibility for policy administrators to adapt to a rapidly changing policy environment.

\section{The dynamic narrative approach}

Marsh and McConnell's framework for policy success is straightforward to apply to a set of data. It contains three dimensions - process, programmatic, and political -, each containing indicators for success and sources of evidence. ${ }^{1}$ However, the authors omit a fundamental of policy practice - the dynamic relationship between narrative and action.

The narrative turn ${ }^{2}$ in policy analysis is now well-established (Jones, McBeth, \& Shanahan, 2011; Ospina \& Dodge, 2005; Roe, 1994; Yanow, 2000) with more recent developments recognizing the value of narratives' performative and dynamic aspects (Hajer \& Laws, 2006; Rhodes, 2011; Van Hulst \& Yanow, 2016; Nicklin, 2015). Policy narrative analysis can be characterized into two types: positivist and post-modernist, respectively (Howlett \& Rayner, 2006). The former traces causality as deriving from a sequence of historical events in a world that exists independently of narratives; the latter is contingent on the situation in a world of ever-present narrative construction and development of shared meanings. The value of post-modern narrative analysis lies in its ability to reveal assumptions and hidden aspects of practice that other forms of analysis cannot, opening up new possibilities for action (Law, 2007). Howlett and Rayner criticize both approaches for being retroactive, and therefore of limited practical application.

This article engages with and seeks to advance on Howlett and Rayner's (2006) case for a combined approach, avoiding the limitations of the positivist form, useful only in a stable policy environment and the post-modernist form, useful only in an unstable one. By combining postmodernist narrative framings with Marsh and McConnell's framework for policy success, this article demonstrates how a blended theoretical approach creates a means for practitioners to reframe and thus more effectively plan for policy success. Rather than treating success as a static result, this approach recognizes success as contingent. In so doing, it addresses some of the difficulties Marsh and McConnell encountered in their analysis, i.e., the methodological problems of weighing successes and failures from multiple outcomes that may also be conflicting, of identifying who is responsible for the success and over what time-period, and of different cultures, values and political systems across different countries.

To address these difficulties, this article significantly develops Marsh and McConnell's framework with four dynamic narrative elements - relational effects, translation, multiplicities and stabilization. These elements are drawn from two theorists whose work considers, but is not often directly associated with, narrative and action: Hannah Arendt and Bruno Latour. Arendt

\footnotetext{
1 - See annex.

2 - While the terms 'story' and 'narrative' are used differently in the fields of narratology and the narrative turn, the above discussion falls in the latter, in which they are synonyms (Hyvärinen, 2004).
} 
sees action as grounded in the political realm and as having an explicit relationship with storytelling. This framing is of particular relevance to the work of government officials responsible for enacting government 'stories' (Arendt, 1998; Thiele, 2009). Latour's work on actor-network theory focuses on revealing the dynamics and relations in the formation of social groupings (Latour, 2007). Latour's aim is to "find the appropriate procedures which render actors able to negotiate their ways through one another's world-building activity" (Latour, 1999, p. 21). The narrative aspects of action are two-fold - the stories inherent in and integral to actors' own actions (narratives-in-action) and the stories that others narrate about what is happening (Latour, 2007; Law, 2000). ${ }^{3}$

Marsh and McConnell depict the relationships between their three dimensions in a Venn diagram that shows them intersecting, with an area in the center where all three circles overlap (Marsh \& McConnell, 2010b). Marsh and McConnell recognize that this model is incomplete, because they seek to test their framework against tensions and contradictions across the three dimensions. Our main objective is to build on the robust foundation provided by McConnell and Marsh and to find solutions to the existing limitations.

Relational effects are the effects of the active connections between people and/or things. These effects occur out of narrative-in-action and from the stories that others relate. For Arendt, action arises out of a story being set in motion - a story over which the initiator has no control, and the outcomes of which neither they nor anyone else can predict. This action, occurring as it does in the political realm (as opposed to the personal realm), is a social, interactive and unpredictable process: "we always act into a web of relationships . . . every action touches off not only a reaction but a chain reaction, every process is the cause of unpredictable new processes" (Arendt, 2003, p. 180). Thus, Arendt's concept of action involves a setting in motion and a chain reaction with multiple unpredictable effects, providing the first clue to current difficulties with identifying policy success.

Latour's contribution is in recognizing that changes in meaning and form occurring out of interactions between actors, both human and non-human, ${ }^{4}$ can be traced. These changes, the 'translations', are the second new element for the framework. Translations build the relations between actors, relations that, in the early formation of an actor-network, are fragile and even transient. Together, these two scholars draw a picture of meaning-making that moves and changes as part of an evolving web of relations. This movement is currently missing from Marsh and McConnell's framework (though present in their discussion on the complexities of policy success) (Marsh \& McConnell, 2010a) ${ }^{5}$.

Translation adds to the understanding of policy success in other ways. The first is by illuminating the nature of uncertainty in policy, and how narrative can help stabilize uncertainty. Paul Ricoeur, in reflecting on the dynamics of translating one language into another, referred to the impossibility of providing an exact representation (Kearney, 2007). This imperfect representation lies at the heart of Arendt's concept of action as an ephemeral thought or intent of an originating actor, picked up by others who make sense of it in their own way. An implication of fragile and changing meaning, such as articulated by Arendt, is that as long as translation is oc-

3 - In this context, narratives do not have to have a beginning, a climax and an end. They can be open-ended, recognizing that 'lived stories' do not necessarily have a conclusion, or even, as will be discussed later, a clear beginning. 4 - Latour also calls the process 'transformation' (Latour, 2007).

5 - Bovens and t'Hart emphasize the asymmetry between political and programmatic dimensions, arguing that for evaluation purposes, the two dimensions operate under different logics (Bovens \& $\left.t^{\prime} H a r t, 2016\right)$. While recognizing the narrative aspects of the political dimension, they fail to recognize the narrative nature of the programmatic dimension. 
curring, matters are not settled. One way of identifying translations, therefore, is through tracing the progress of debates, or narratives-in-action (Latour, 2007). Tracing the progress of debates may thus reveal the presence of tensions and contradictions, and how they are resolved.

The third element is multiplicity, recognizable in Marsh and McConnell's statement that policy can produce outcomes that are "multiple and conflicting"(Marsh \& McConnell, 2010a, pp. 578-579). Given the narrative nature of policy (Hajer \& Laws, 2006), multiple outcomes imply multiple narratives. In actor-network theory, multiple narratives arise from the different and contested meanings from actors in constantly evolving actor-networks. In other words, action is the process of negotiating multiple narratives. These narratives derive from multiple sources, some of which can be traced back long before the policy began, with subsequent consequences of success (Nicklin, 2015). Both Arendt and Latour argue that there is a never-ending trail of preceding events for every supposed initiating event (Arendt, 1998; Latour, 1987; Thiele, 2009). The dynamics of translation are affected by these antecedents and must be given due weight across all three dimensions.

The fourth element is stabilization. Success implies a stable state. If one considers success as an end-point, the question of instability and uncertainty, and therefore stabilization, does not arise. If one considers success as contingent, however, instability and uncertainty cannot be ignored, and stabilization becomes important. Arendt and Latour provide a means through which to understand the dynamics at play when meaning, and therefore action, is stabilized.

For Latour, action manifested through translation stops only when the translation stops. At this stop-point, something has been stabilized - for example, an agreed upon idea, or design, or standard - which means it can be captured in a document or in a final concept. ${ }^{6}$ This capturing plays an important part in stabilizing policy, albeit temporarily. For Latour, and to some extent Arendt, stabilization comes from actors accepting a particular set of meanings at a particular point in time (Latour, 1987). This acceptance enables the documenting of the current state of meaning or the current narrative. It also means the narrative can be shared with others who may then accept and, each in turn, promote or develop the matter further.

Bringing these ideas together provides the elements of a dynamic narrative approach relevant to policy success, i.e., concepts of relational effects, multiplicity and stabilization, driven and woven together by translation. In this approach, narrative and action are inextricably connected through both human and non-human actors. Officials act out narratives and translate them into tangible results through traceable webs of relations. Narratives are multiple and changing as meanings and forms circulate in networks of translation, bringing with them uncertainty and fragility. Stabilizing points can help with identifying the progress of contestation and tracing success or multiple successes. Table 1 below reflects the above discussion. It represents the four new elements as cutting across the three policy dimensions in Marsh and McConnell's framework, thereby creating a new analytical tool.

6 - Or simply abandoned. 
Table 1. Dynamic Narrative Policy Success Framework

\begin{tabular}{|c|c|c|c|c|}
\hline & Dimension: & Political & Programmatic & Process \\
\hline & & $\begin{array}{l}\text { Legitimacy in } \\
\text { the formation } \\
\text { of choices, sus- } \\
\text { tainability of } \\
\text { support, inno- } \\
\text { vation and in- } \\
\text { fluence }\end{array}$ & $\begin{array}{l}\text { Policy objec- } \\
\text { tives, desired } \\
\text { outcomes, re- } \\
\text { sources and } \\
\text { the benefits of } \\
\text { policy for the } \\
\text { relevant actors }\end{array}$ & $\begin{array}{l}\text { How the policy } \\
\text { question, the } \\
\text { options, and the } \\
\text { consultations } \\
\text { were framed, and } \\
\text { how the deci- } \\
\text { sions were made }\end{array}$ \\
\hline Element & & & & \\
\hline $\begin{array}{l}\text { Relational } \\
\text { effects }\end{array}$ & $\begin{array}{l}\text { "Where are tl } \\
\text { likely effects } \\
\text { "Where and } \\
\text { programme a }\end{array}$ & $\begin{array}{l}\text { shifting relationsh } \\
\text { ose shifts on succe } \\
\text { are the effects of } t \\
\text { olitical narratives? }\end{array}$ & $\begin{array}{l}\text { ps between actors, } \\
\text { s?" } \\
\text { e shifting relations }\end{array}$ & $\begin{array}{l}\text { and what are the } \\
\text { between process, }\end{array}$ \\
\hline Translation & $\begin{array}{l}\text { "Where are } \mathrm{t} \\
\text { the policy/pr } \\
\text { involved?" } \\
\text { What narrati }\end{array}$ & $\begin{array}{l}\text { ranslations occurr } \\
\text { changing as a re } \\
\text { re being acted out }\end{array}$ & $\begin{array}{l}\text { ng, how is the me } \\
\text { ult, and who or w } \\
\text { hrough the transla }\end{array}$ & $\begin{array}{l}\text { aning or form of } \\
\text { hat are the actors } \\
\text { tions? }\end{array}$ \\
\hline Multiplicities & $\begin{array}{l}\text { "Where are tl } \\
\text { "Where are } \mathrm{t} \\
\text { need to be res } \\
\text { "Where can } \mathrm{n}\end{array}$ & $\begin{array}{l}\text { ultiple narratives } \\
\text { itical points in the } \\
\text { d?" } \\
\text { ple narratives be to }\end{array}$ & $\begin{array}{l}\text { ming from or likel } \\
\text { project at which } \mathrm{n}\end{array}$ & $\begin{array}{l}\text { y to come from?" } \\
\text { ultiple narratives } \\
\text { yerse effects?" }\end{array}$ \\
\hline Stabilization & $\begin{array}{l}\text { "Where are tl } \\
\text { "Are they con } \\
\text { "Where can } t\end{array}$ & $\begin{array}{l}\text { certainties?" } \\
\text { able or systemic?" } \\
\text { licy narrative be s }\end{array}$ & abilized?" & \\
\hline
\end{tabular}

Source: the Author

By applying this new framework to empirical data, this article shows how it illuminates and to some extent addresses the issues with Marsh and McConnell's framework and thus develops it.

\section{Methodology}

The empirical study in this article is a re-examination of data from a larger research project on trans-Tasman border management (Nicklin, 2015). It traces the particular case of the development, between 2009 and 2012, of a new passenger clearance model for travel between Australia and New Zealand. This work was initiated by the joint prime ministerial statement of March 2, 2009 (Key \& Rudd, 2009a). The case covers the subsequent development and eventual abandonment of the work on the new model. 
The value of this case study is three-fold. First, on the face of it, the policy was not a success. It is therefore an excellent candidate for revealing hidden aspects of practice, and thus illustrating the value of a dynamic narrative approach. Second, it highlights the usefulness of border management policy for studying the effects of the tension between the economic and security interests in the study. Third, it shows how cross-jurisdictional policy work is affected by two countries geographically separated by a sea. While many countries share land rather than sea borders, the dynamics in this case will be recognizable across many domains. The case is particularly relevant for the United Kingdom in a post-Brexit world. It also highlights pressure points and essential connections that may be harder to detect in a single jurisdiction. For example, while the effects of differing priorities for different agencies, the effects of processes, structures and systems on the speed of work, and the mitigating effects of good relationships are common to all policy work, they become amplified in a cross-jurisdictional setting.

Primary data for the study was drawn from trans-Tasman official records from 2009 to 2012, including agendas, minutes, working papers and ministerial statements relating to the development of the trans-Tasman model, and from 33 interviews conducted between 2013 and 2015 with officials from Australia and New Zealand involved in the projects at various levels of their organizations. The choice of examples was determined by their applicability to the three dimensions in the framework and as illustrations of the dynamic elements in Table 1.

The analysis is structured around each dimension of success. It then seeks to interrogate the data by reference to the additional 'tests' suggested by the dynamic aspects reflected in Table 1. The key question at this juncture is whether the enhanced heuristic more fully elaborates the nature of policy success. To anticipate the answer to this question, this article contends that it is most decidedly in the affirmative. The 'dynamic overlay' provides a more complete set of understandings. Lastly, the implications for policy practice are then identified.

\section{Background to the empirical study}

The Australian and New Zealand governments operate in an environment of shared cultural heritage as ex-colonies of Great Britain and current members of the British Commonwealth, and of economic integration brought about by the Australia-New Zealand Closer Economic Relations Trade Agreement in $1983 .{ }^{7}$ Supporting these connections are multiple bilateral government-to-government relationships, involving meetings between ministers of the Crown and between officials. Unusually for two sovereign nations and relevant to the empirical case, their Departments of Prime Minister and Cabinet, representing the interests of their respective prime ministers, work closely together, particularly when preparing for and reporting back on bi-annual prime ministerial meetings.

In March 2009, the Prime Ministers of Australia and New Zealand issued the customary joint statement after their February meeting, outlining their agreed actions. The statement included an objective to "reduce remaining barriers at the borders to ensure people and goods can move more easily between the two countries" (Key \& Rudd, 2009a). Both countries' Departments of Prime Minister and Cabinet joined forces to drive this objective, communicating to border agencies their high expectations of a list of 'announceable' initiatives for the second prime ministerial meeting which was to be held on August 20, 2009. One of these initiatives was a study to describe the options for a new trans-Tasman passenger clearance model; a second step, an-

7 - The monarchy of the United Kingdom is still the constitutional head of state in both countries - "the Crown" in statutes. 
nounced in 2011, was the design of a 'domestic-like experience'. By July 2011, the new model had been developed but it was never implemented. While border priorities appeared similar, Australia's political focus largely shifted over the period of the study toward security, and New Zealand's became more domestic.

\section{Analysis}

Using the framework in Figure 1, the discussion below examines the dynamics behind these events and how they relate to success.

\section{Political dimension of success}

Marsh and McConnell's political dimension covers the popularity of a policy and its impact on a government's reputation and election chances. February 2009 saw newly elected New Zealand Prime Minister, John Key's first official meeting with the Australian Prime Minister who had been in office for only one year, Kevin Rudd. This meeting provided a chance to set a new agenda and for Prime Minister Key to prove, through early successes, ${ }^{8}$ that his was going to be a pragmatic government. ${ }^{9}$

This notional start point is important for our examination of success. It was the point at which multiple narrative threads from a range of different actors, both human and non-human, came together in a joint political statement (Nicklin, 2015). These narrative threads were in the briefings from officials from both countries, the pressure from lobby groups, the established practice of bi-annual meetings, and accompanying processes that generated actions that could be announced in joint statements and the personal priorities of each Prime Minister. For example, Prime Minister Key was interested in the border clearance arrangements operating between the United States and Canada (Border Sector Governance Group, 2009). In the background, there was pressure from the Australia-New Zealand Leadership Forum which was pushing for a common border (Holmes, 2004). In addition, the Australian airline industry had been launching a series of attacks on their government since the early 2000s on increasing government taxes and costs of air travel (for example, Creedy, 2004; Riley, 2003). The announced objective heightened the chances of a political change of policies they considered negatively affected passenger numbers. The prime ministerial talks provided a point of convergence for these multiple narratives. This could be considered a political success not only for John Key, but for all the different actors who were seeking political attention on the trans-Tasman borders. The Prime Ministerial statements were so generic that all interested parties were able to believe their needs were being represented.

The joint statement of March 2, 2009 set in train significant work by officials who prepared a series of proposals for the Prime Ministers to discuss at their meeting on August 20, 2009. Following the second announcement, there was a strong commitment to the new policy: "The Prime Ministers agreed that . . . both governments would bring sustained focus to making new progress in: * further streamlining of trans-Tasman travel, working toward full implementation of a new trans-Tasman passenger clearance model..." (Key \& Rudd, 2009b) (author's emphasis). This implied the delivery of a clearly different set of arrangements for passenger clearance.

\footnotetext{
8 - Source: Interviews.

9 - See, for example, 2009 Scoop News, http://www.scoop.co.nz/stories/BU0903/S00467.htm and 2011 National Business Review: https://www.nbr.co.nz/article/nz-politics-daily-why-john-key-so-popular-96508, both accessed 9 November 2017.

10 - From Kevin Rudd to Julia Gillard in a leadership coup in 2010.
} 
Between 2009 and 2011, there was a change of leadership in the Australian government. ${ }^{10}$ This change affected the interactions between the two government leaders and the political intentions for the development of the trans-Tasman passenger clearance model. The effects of this change can be seen in the narratives and the outcomes of the initiatives. In line with transTasman practice, the biannual joint Prime Ministerial meetings continued after the leadership change, maintaining the regular connections between the new Australian Prime Minister, Julia Gillard, and John Key. A softening of the intent can be correlated with the change of leadership. : "The Prime Ministers further welcomed the positive steps aimed at making travel across the Tasman a domestic-like experience, including ... joint studies looking at further improvements to trans-Tasman travel" (Key \& Gillard, 2011). ${ }^{11}$ This change implied a more gradual and less immediately obvious set of changes to passenger clearance. It also used the 'domestic-like' language officials had translated into their work from Prime Minister Key's 2009 comments: "Australia's a very important market to New Zealand. Over a million tourists a year now come to New Zealand, so whatever we can do to make that process less painful, to make it more like a domestic experience ${ }^{12}$ and to streamline it, I think is very important" (Unnamed journalist, 2009).

After 2011, the Prime Ministerial meetings continued, as did the changes to the narratives about trans-Tasman travel. The joint statements from those meetings omitted mention of the new model, focusing instead on automated passenger processing technology. References to joint border action of any kind was absent after 2012,13 indicating an excising of the new model from political narratives. ${ }^{14}$ The comments from an official in 2013 support this conclusion:

Industry's keen, but I just didn't get the sense that anyone's screaming out in Government to push really hard, 'cause they feel that everything we're doing individually is moving towards that goal (New Zealand (NZ) Official 9).

This comment suggests the convergence of interests into a single narrative was temporary and was starting to diverge, with a slowing effect on the momentum of the action. Even so, the temporary convergence was a stabilizing point that enabled officials to translate political intentions into the range of proposed initiatives announced in August 2009. This second round of announcements was arguably another political success.

Under Marsh and McConnell's framework, this initiative could be considered politically unsuccessful because the model was not delivered and the tourism industry was still calling for change, as evidenced in the wide New Zealand media coverage in September 2017 of a report from the Tourism and Transport Forum Australia. The report called for a simplification of trans-Tasman border processing, promoting many features remarkably similar to those in the unpublished model of $2011 .^{15}$

However - and this is a significant insight -, under the new framework of Table 1, success is evident in the relational effects observable in a long tail of further improvements after 2011. These improvements arose from an ongoing acting out of the trans-Tasman narrative in the form of incremental changes to trans-Tasman passenger clearance processes. For example,

11 - Author's emphasis.

12 - This phrase becomes important later.

13 - The last reference to joint activity in passenger clearance was in 2012, accessed at https://www.beehive.govt.nz/ release/joint-statement-prime-minister-key-prime-minister-gillard

14 - Whether or not this was deliberate or merely a shifting of attention to other priorities is not clear. It may have been a case of 'performative silence' (McGoey, 2012, p. 7)

15 - See NZ Herald item on the report, accessed from http://www.nzherald.co.nz/business/news/article.cfm?c $\mathrm{id}=3 \&$ objectid $=11926579$ 
Australia extended and enhanced its automated processing capabilities in $2015^{16}$, and New Zealand introduced a 'trusted traveller' pilot in 2016. ${ }^{17}$ The drivers of these incremental developments are not visible at the political level. Rather, the programmatic and/or process relations are the likely source. Given the systemic and structural connections between politicians and officials, this is hardly surprising. Perhaps less obvious is that political success may not just be connected with officials' actions but may depend on the relational effects of those actions in the program and process dimensions.

This analysis has shown how existing relations in the form of traditional trans-Tasman prime ministerial meetings provide a vehicle for new trans-Tasman political narratives. It has traced the birth of a particular political narrative as a convergence of multiple narratives. It has shown how that convergence was only temporary but survived long enough for officials to translate it into politically successful announcements. It has also traced changes to political narratives that correlate with changes to political leadership, highlighting the uncertainty of the political dimension for officials who are required to translate those narratives into action. The analysis has also shown that relational effects can be traced beyond the life of the political narratives, suggesting that forces beyond the political maintain action. None of these insights would have been visible under a static analytical model.

\section{Process dimension}

The process dimension covers the elements of the policy process in the case study, i.e., the framing of the policy question, the options, the consultations and the decisions made. Legitimacy is important, as is "a sufficiently powerful coalition of interests" (Marsh \& McConnell, 2010a, p. 572).

In the empirical study, a multiplicity of formal and informal relations between the actors (webs of relations), including structures and processes, affected all aspects of the policy process: the framing of the problem, the options for the new model, the consultation and the ways in which decisions were made. The actors in these existing relations, drawn from the three core border agencies $^{18}$ on each side of the Tasman Sea, acted out well-established narratives of cooperation through functional bilateral relationships: customs to customs, immigration to immigration and biosecurity to biosecurity. ${ }^{19}$ The work on the new model necessitated a bringing together of the bilateral connections into a new collective border agency relationship between the two countries. This new aspect of the relationship was fragile and will be discussed below in the 'program' dimension.

In New Zealand, an existing coordination mechanism under the umbrella of a chief executive group called the Border Sector Governance Group managed the 'new model' policy process. The Border Sector Governance Group was a key decision-making body, gatekeeping proposals officials presented to the government. The Border Sector Secretariat (the Secretariat), which coordinated agency input and translated it into the collective voice of the New Zealand border sector, coordinated New Zealand's policy input. In Australia, there was no such border hub.

16 - See the joint Prime Ministerial statement accessed from https://pmtranscripts.pmc.gov.au/release/transcript-24240

17 - Media coverage of the trial in 2016 and 2017, accessed from: http://www.nzherald.co.nz/business/news/article. cfm?c_id=3\&objectid=11645602 http://www.nzherald.co.nz/business/news/article.cfm?c_id=3\&objectid=11929986 18 - At the time, in New Zealand, the New Zealand Customs Service, the Ministry for Agriculture and Forestry and the Department of Labor (Immigration NZ); in Australia, Australian Customs and Border Protection Service, Australian Department of Agriculture, Fisheries and Forestry, Australian Department of Immigration and Citizenship.

19 - For example, through expectations of shared training and operational information sharing. 
Instead, the then Australian Customs and Border Protection Service coordinated input from Australian border agencies via a nominated manager. These two coordinating mechanisms were the main conduit of information and debate across the Tasman Sea. They were also the means by which officials not only translated the Prime Ministerial announcements into action, but also produced the joint advice that resulted in the 'domestic-like' study being legitimated in the 2011 joint statement (Nicklin, 2015). These coordinators were central to stabilizing the translations and thus the progressive development of a joint trans-Tasman narrative that then drove the work program. Each occasion on- which officials came to an agreement could be considered a policy success.

The constraints of physical separation added instability by affecting the nature and timing of the whole policy process, and thus the narratives being enacted. The physical barrier of the Tasman Sea pushed officials toward the easier choice of separate rather than joint policy development. ${ }^{20}$ In what could be characterized as an interrupted policy process, officials in each country developed their input separately, coming together for infrequent joint meetings via the vicissitudes of unreliable video conference technology. This separation slowed down the overall process: The first phase of the work took five times longer than planned, the second twice as long. The two coordinators played a key role in translating each others' narratives on their officials' behalves. It was a process success that these coordinators sped up the policy process, resolving debates and working through difficulties before joint meetings (Nicklin, 2015).

The framing of the policy work started with multiple narratives that began separately, with the narratives in each country influenced by their own policy processes, traditions and political priorities, as well as those of the agencies involved. At the beginning of the policy process, there were no adverse effects from the differences. It could be considered an example of 'calculative ignorance', where maintaining ambiguity about the purpose of the work enabled agreement (Mallard \& McGoey, 2018, p.901). For example, there appeared to be different underlying reasons in each country for employing an independent contractor, as described by one New Zealand official (and echoed by others):

For them [Australia], it was an exercise in getting an independent body to show how tricky it might be - that how long term it would be, how much it might cost. From New Zealand's point of view, we had a slightly more purist attitude that something independent would be a genuine basis to engage with the industry, 'cause industry had its own ideas about what passport-free, or borderless travel, or removing the remaining barriers looked like ... So I think . . . both countries had their sort of different agendas for [the study] (NZ Official 5).

The policy success lay in officials from both countries agreeing on the process. The different reasons for the study became material when the contractors began their work. Officials debated the scope, meaning and definition of the work, policy plans, the content of draft reports, the draft model and the additional work arising from the model. Officials in each country, particularly in New Zealand, debated the consultant's policy options before accepting the reports. This process involved resolving multiple narratives through repeated translation. The progressions of the shifting meaning-making in these debates can be traced in the meeting minutes.

Officials appeared to rely on process to drive the momentum, rather than on a coalition of interests. There was no unified external coalition of interest to drive momentum. Australian

20 - Given a two-hour time difference, three-hour airplane journey, and time-consuming airport transfers and domestic flights. 
industry stakeholders were pushing for a change that the Australian government had signalled it was not going to make, while New Zealand industry stakeholders generally supported the work of officials (Nicklin, 2015). At the working level, officials had a duty of care to honor the contract signed with the contractors, in terms of timeframes and acceptance of their reports. Achieving contract milestones were critical points at which narratives had to be resolved. The dynamics of doing so affected the timeline significantly as mentioned earlier.

This discussion points to a translation effect in process success - the ability of officials to keep the process moving in the face of obstacles -, because if there is no translation, there is no movement. In this case, the records that traced the resolution of the many debates contained the evidence for this aspect of process success. These resolutions enabled the work to progress, despite uncertainties and delays. The adoption of the term 'domestic-like' by the prime ministers in 2011 was a legitimation of this progress; the fact that a new model was developed was arguably a triumph of keeping the momentum going and could be considered a process success.

Marsh and McConnell suggest that evidence for the success of process is relatively straightforward. However, the trans-Tasman study highlights the high degree of uncertainty in the process of creating the new model. As the program dimension will show, this uncertainty made it difficult for officials to enrol others in the work, and thus to gain the executive and political support and legitimacy they needed to make progress. Creating new policy, and particularly a new model, is like sculpting a figure out of a block of sandstone. At the start, it is invisible, in a state of imminence; part way through it is a confusing mix of unformed and partly formed shapes. It is not until the model is nearly developed that its shape becomes clear, and others can visualize what it will look like. It is only then that people outside the work can decide to buy into it or not. This has implications for policy effort. Czarniawska highlights this need of visibility for ideas to travel: "Neither can words or images travel until they have materialized, until they are embodied or objectified" (Czarniawska, 2009, p. 425). In this case, progress reports reassured the governance level that the process was moving. When the report describing the new model was revealed in 2011, a diminished appetite by officials and, it would seem, by industry representatives, was evident. They could see it was unlikely to be cost-effective, and therefore unlikely to get the political financial support it needed. While programmatic influences were at play on the suspension of the work, it could also be concluded that officials not pressing for an unfeasible policy was a small process success.

In summary, following translation provides a window into the relational effects of the policy process; it reveals the changes in pulling multiple stories into an agreed version, and the importance of stabilization for making and showing progress in its formative stages, particularly politically. Within these areas can be seen different types of process success - agreeing on the process, agreement on stabilized narratives, development of a new model in the face of obstacles, and not pushing for an unfeasible implementation.

\section{Programmatic dimension}

This dimension covers the objectives, outcomes, resources and benefits of policy for specific actors. These elements play out in a policy program through its structures. The case study shows how relational effects, multiplicity and instability illuminate the interplay of these elements and of the programmatic dimension with the other two dimensions.

In 2009, the objectives and outcomes were clear but the path to achieving them was not. The announcement on August 20 specified the objective of the program, i.e., to implement a new trans-Tasman passenger model. The program evolved stage by stage, each stage with a deliver- 
able: a feasibility study, the design of the new model, and the implementation. This is a familiar approach to a large project. The notable aspect in this case is that these stages were not there at the beginning. This may have been, as previously signalled, calculative ignorance on the part of officials. Rather than starting with a grand plan, officials started modestly, staying silent on subsequent steps. The completion of each step provided the narrative to be enacted in the next phase. In other words, from the initial uncertainty about scope of change and funding (Australian and NZ officials, 2009), each new phase progressively emerged as the narrative stabilized. For example, the feasibility report presented five options. Politicians made it clear that they wanted a new model within the existing paradigm, not a new paradigm (Nicklin, 2015). Officials used this stabilized scope to develop the 'domestic-like experience'. This incremental approach could be considered an overall programmatic success, with the completion of each stage a progressive success.

By 2011, multiple objectives and narratives on both sides of the Tasman Sea emerged, reducing the focus on the new model to the point that chief executives from both countries decided not to provide resources to implement it By the time the new model was submitted for implementation, the focus of the New Zealand Border Sector Governance Group had shifted away from a trans-Tasman model to the future of the New Zealand border. Structural change in two of the New Zealand border agencies and a highly complex joint border management computer development triggered this change:

[Chief executives] asked us to go away and do some further thinking about "what are the implications". We did some work on the implications, and then that was handed over . . . and essentially, the consideration of that was put on hold because of the future of the border (NZ Official 10).

In other words, the New Zealand chief executives declined to translate the preliminary implementation plan into an allocation of resources, prioritizing instead New Zealand-focused work. At the same time, Australian officials were shifting their focus from the new model to managing increasing passenger volumes, along with a political shift of focus away from facilitation and toward border security. ${ }^{21}$ Neither country contested the decision not to proceed with implementation at the senior executive or political levels. Their changed priorities to domestic narratives happened to coincide, enabling agreement. This decision could be considered a serendipitous programmatic success.

These changes were programmatic but they were also political. Political decisions on both sides of the Tasman Sea drove them, affecting the priorities that senior executives were working toward. A 2012 Cabinet report on the New Zealand border sector referenced the 2009 joint prime ministerial statements on trans-Tasman passenger processing: "as an expectation that both countries will work towards a 'domestic-like' experience for trans-Tasman travellers” (Office of the Minister for Primary Industries, Office of the Minister of Immigration, \& Office of the Minister of Customs, 2012, p.4). However, it stopped short of specific actions. This absence received neither observable political nor media criticism at the time. In addition, the Australian airline industry received a clear political message that there would be no reduction in costs. They therefore shifted their focus away from the new model:

And I think it goes back to my earlier point about. . . the level of interest that industry had in investing in some of the changes that would need to be made, noting that ... again that issue of them all wanting a solution for them, which would give them 
a competitive advantage; and the other factor being that the Passenger Movement Charge was non-negotiable. Yeah, so it sort of, in my view, took the wind out of the sails (Australian Official 5).

In the case study, program structure had particular relational effects. John Law describes structure as "not free-standing, like scaffolding on a building-site, but a site of struggle, a relational effect that recursively generates and reproduces itself" (Law, 1992, p. 5). First, as described earlier, the program operated out of two different countries and involved an interrupted policy process. There was no strong joint mechanism to drive and build a common narrative for the work (the Secretariat and Australian coordinators could be considered 'light touch'). This lack of a joint structure affected the translations and thus the progress and potentially, the nature of the work. One official commented: "If you're really going to have a joint system, . . . it can't be just us talking to them occasionally. It has to start getting a bit of a 'we' thing happening, and we never did get to that" (NZ Official 10). This comment raises questions about what could have been possible with a joint program structure.

Second, the resourcing was different in each country. In New Zealand, the individual agency connections coalesced in the Secretariat, which maintained the narrative momentum: "the very programmed work of the border sector, I think, was very good in keeping a very clear focus on key areas and providing very clear incentive and driver for activity to be undertaken" (NZ Official 18). The Secretariat "worked as a sort of glue or conduit for all those different connections between different agencies" (NZ Official 10). The effect of this 'glue' was particularly evident in the meeting minutes of the working level officials. Processes of translation could be seen in the evolving debates. The translation effect reduced further up the structural chain, as evidenced by the number of meetings held at the respective levels. ${ }^{22}$ Senior officials were not required to engage with the content of the policy work to the same degree as the working group, focusing more on the programmatic aspects. In addition, senior executives were also focusing on other initiatives (Nicklin, 2015). An effect of these different dynamics meant that the working group was focused but the decision-makers were affected by multiple and diverse organizational narratives as illustrated above.

The examination in the programmatic dimension reveals political and process dimension effects on different types of program success: adopting an incremental approach in the face of uncertainty, achieving stabilized narratives within that approach, and a serendipitous success where two countries' shifting narratives coincided in a mutual decision. This discussion also highlighted the structural uncertainties of working on a joint cross-jurisdictional policy program without a joint program structure.

\section{What the dynamic narrative approach adds to the study of policy success}

The preceding discussion demonstrates very clearly the benefits of developing the static model advanced by Marsh and McConnell through the addition of four dynamic narrative elements. It also shows that dynamic narrative analysis reveals additional aspects of policy success that address the problems and gaps with Marsh and McConnell's framework identified earlier. First are the methodological problems of weighting success and failure for multiple, and especially conflicting, outcomes. The case study has revealed that the interplay of multiple narratives

22 - In New Zealand between 8 July and December 2011, there were eight working group meetings , two senior officials meetings, three Border Sector Governance Group meetings, and one video conference with Australian officials (Nicklin, 2015, p. 204) 
changes the nature of the question 'whose success?'. This interplay suggests there is no need to search for a single success, or the right success. There need be no limit on the number of successes. The analysis has shown that success can be a programmatic decision not to proceed, or to keep the process going in the face of obstacles, or incremental improvements that reflect the continuation of a political narrative in the background. Success could equally be new thinking prompted by an impossible deadline; it could be a community galvanized to act. Multiplicity is liberating, opening up evaluation to new elements.

If this is indeed the case, there will be different types of successes at different points in the policy process. This is quite different from McConnell's spectrum of policy success (McConnell, 2010) which contains static descriptions and lacks the effects of time and networks. In the dynamic narrative approach, success (and failure) become relative to the context, such that even if there is an overall failure, small successes within that failure can still be recognized and acknowledged. Such an approach suggests a taxonomy of small successes built from officials' experiences and evidence that could be documented in a 'living' database. This approach may make transparent, at least to officials and politicians, the range of successes that have been claimed, and can thus act as examples for use in the future.

Second, the dynamic narrative approach reframes tensions and contradictions through narrative translation. Tracing the translations makes visible the ebb and flow of the narrative changes. The points when ideas are discarded, when multiple stories start to coalesce into a more agreed package, and when an original idea is tempered to reach an agreement, all become relevant to understanding and evaluating success. For example, in the 'new model' work, the movement of intersecting and overlapping interests became visible in the debates on the final draft of the first consultant report. Within New Zealand agencies, it took many meetings to get to a New Zealand position; the data also showed a seesawing of position within Australian Customs and Border Protection. This movement caused delays that negatively affected the programmatic success of this work, highlighting the impact of uncertainty on delivery. However, a small success was the coming to agreement, each country separately, then together.

This examination has also confirmed that Marsh and McConnell's framework fails to accommodate the shifting nature of relations. There is a resonance here with Bovens and t'Hart's "constructed, negotiated and therefore contingent" nexus between reputation (political) and performance (programmatic)(Bovens \& t'Hart, 2016, p. 658). The webs of relations in organizational structures align with each dimension: political and executive-level relations with the political dimension; management-level relations with the programmatic dimension, and relations between working level officials with the process dimension. Moreover, the analysis suggests that these webs cross deeply into one another's territory and beyond. Political narratives frame the ways in which officials use and shape the management expectations and working level mechanisms, while at the same time, process and program activities are translated into political narratives; process mechanisms frame the program design, creating boundaries around outcomes, resourcing and delivery, while being shaped at the same time by programmatic requirements such as timeframes and stakeholder interests. The narratives being enacted, and therefore their success or otherwise, depend not only on their relations with one or more of the dimensions of success but also on wider webs of relations.

The narratives that are part of these webs of relations provide not only the glue that links the dimensions, but also make visible the uncertainties contained within them. These uncertainties result in a dynamic, shifting relationship across the dimensions and thus affect what we mean by successes. This visibility could help managers predict where slowing effects might 
occur on the narrative 'chain reaction'. In addition, acknowledging the tensions and contradictions that were overcome is an example of this more differentiated view of success.

The new framework of Table 1 will be of particular use for officials during the planning and implementation stages of policy. Existing webs of relations, the need for new connections, and places where critical translations need to occur can be identified and then tracked. Such planning will enable the collecting of evidence from the work and the progressive communication of multiple successes. Measures of success could help identify how well officials embrace and mitigate the effects of uncertainties and new, fragile connections that enable flexibility and agility. This flexibility provides room "for something different to occur" (Nicklin, 2015). This 'wriggle room' is essential in a complex policy environment that increasingly demands innovation new ways of working and being responsive to customer needs (Bason, 2016).

The study also highlighted the importance of two everyday stabilizing mechanisms inherent in most policy work. The first is that drawing on existing connections between key individuals and existing structures, such as regular trans-Tasman meetings, and in the case of the New Zealand border agencies, the chief executive Border Sector Governance Group, helps stabilize and therefore strengthen fragile connections. The second is that documenting progress in the form of diagrams, meeting minutes and reports also makes progress visible and portable, and thus easier to communicate to others. The more the agreed meanings are shared, the more they can be developed further and used to engage others in the work.

A wider implication from this discussion is that a dynamic narrative approach demands that we think differently about what policy success is and what it means. It reframes policy success into a contingent and shifting story-scape across the progression of a policy's life and beyond. ${ }^{23}$ The answers to questions of defining and claiming success depend on their relationship to the actors and the stories being enacted. This reframing appropriately allows multiple interpretations of success in a world of complexity.

This approach also raises questions. For example, if success changes as the webs of relations and the narratives change, how can success be captured, and how can it be verified independently? If there are multiple narratives that may, but do not have to, coalesce into a single narrative, is there not an issue with selectivity, and the potential for distortion and misrepresentation? Part of the answer is that these are 'point in time' questions. Following the actors, as Latour exhorts the researcher (2007), leads to a progression, i.e., to a story of movement that is traceable. The stabilization mechanisms provide markers within that movement that enable validation.

\section{Conclusion}

The point of departure for this article has been to argue that policy success is not only multifaceted, as presented by Marsh and McConnell, but also dynamic, with important implications for theory and practice. Using the work of Hannah Arendt and Bruno Latour in a new framework that builds on and significantly enhances the work of Marsh and McConnell, this enquiry has focused on illustrating the dynamic effects of narrative on policy success through a transTasman border management case study.

This approach provides two key insights. First, multiple success points mean there is more than a single answer to the question of policy success, even within each dimension, but also that a single answer is unnecessary. Freed from numerical constraints, successes can be acknowledged in their multitudes. 
Second, Marsh and McConnell's framework is useful, but the connections between the dimensions are more significant than these authors contend. These connections comprise deep webs of relations that carry and translate narrative. Some webs are historical, systemic and structural, many originating outside the dimensions; others are new and fragile. The former play a stabilizing role, while the latter provide the space for new ways of doing things.

These webs are the locus of multiple, shifting stories of success, and contain within them the potential for a progressive taxonomy of success. Policy deliverables are not only the end-point. Indeed, there are multiple success points within the development and implementation stages of a policy that can be measured, recorded and acknowledged. A taxonomy of successes has the potential to provide more transparency in when and how political success is claimed. This potential demands further exploration.

These insights have implications for the framing of policy success and, therefore, how this success is measured and evaluated. Reframing policy success in this way creates a change within the existing paradigm that is material and significant. Policy success moves from the end-point to a relational and shifting story-scape that progresses throughout the life of a policy. This change comes from tracing how and where the action moves, and from telling multi-layered, differentiated stories of policy successes across time and space. This new framework provides a platform for increasing the likelihood of larger policy successes by facilitating up-front planning using the Dynamic Narrative Policy Success Framework, and tracking the trajectory of successes. A database of policy successes may provide transparency about identified successes and assist in their communication.

Most importantly, existing frameworks provide only partial insights. By drawing on Arendt and Latour, this article advances a new framework that is forward-looking, and thus able to address the criticisms of narrative policy analysis as retroactive. In so doing, it provides an account of policy success that allows for much-needed space and flexibility in a complex and rapidly changing policy world.

\section{Bibliography}

Arendt, H. (1998). The human condition (2nd ed.). Chicago, IL: University of Chicago Press.

Arendt, H. (2003). The Portable Hannah Arendt. United States: Penguin Books.

Australian and NZ officials (2009). Trans-Tasman Passenger Facilitation Teleconference (Minutes No. Reference Document 6). Canberra: Department of Prime Minister and Cabinet.

Bason, C. (Ed.). (2016). Design for policy. Abingdon, Oxon: Routledge.

Border Sector Governance Group (2009). Trans-Tasman Travel. Wellington, N.Z: Border Sector Governance Group.

Bovens, M., \& t'Hart, P. (2016). Revisiting the study of policy failures. Journal of European Public Policy, 23(5), 653-666.

https://doi.org/10.1080/13501763.2015.1127273

Bovens, M., T'Hart, P., \& Peters, B. G. (Eds.). (2001). Success and Failure in Public Governance: A Comparative Analysis (1st ed.)). Cheltenham, UK; Northampton, MA: Edward Elgar Publishing. 
Creedy, S. (2004, October 9). Industry outraged at Labor plan to raise passenger levy. The Australian p. 29. Retrieved from http://ezproxy.massey.ac.nz/login?url=http://search.ebscohost. com/login. aspx ?direct $=$ true $\& d b=a n h \& A N=200409101029906339 \&$ site $=$ eds-live\&scope $=$ site

Czarniawska, B. (2009). Emerging Institutions: Pyramids or Anthills?, Organization Studies, 30(4), 423-441.

https://doi.org/10.1177/0170840609102282

Hajer, M., \& Laws, D. (2006). Ordering through Discourse. In M. Moran, R. E. Goodin, \& M. Rein (Eds.), The Oxford Handbook of Public Policy (pp. 251-268). Oxford: Oxford University Press.

Holmes, F. (2004). The Australia New Zealand Leadership Forum: Reflections on its Proceedings. (Informal). Wellington, N.Z. Retrieved from http://igps.victoria.ac.nz/events/downloads/LeadershipForum.doc

Howlett, M., \& Rayner, J. (2006). Understanding the Historical Turn in the Policy Sciences: A Critique of Stochastic, Narrative, Path Dependency and Process-Sequencing Models of Policy-Making over Time. Policy Sciences, 39(1), 1-18.

doi:10.1007/s11077-005-9004-1

Hyvärinen, M. (2004). The conceptual history of narrative: An outline. In Conference (pp. 3-4). Retrieved from http://128.214.21.166/collegium/events/narrative_hyvarinen.pdf

Jones, M. D., McBeth, M. K., \& Shanahan, E. A. (2011). Policy narratives and policy processes. Policy Studies Journal, 39(3), 535-561. Retrieved from http://go.galegroup.com/ps/i.do?id=GALE\%7CA26 $5024098 \& v=2.1 \& u=v u w \& i t=r \& p=A O N E \& s w=w \& a s i d=f 21 d 5 c 3 c 597 b 0 f 48 e 79750 d 36 d 95 f 34 a$

Kearney, R. (2007). Paul Ricoeur and the Hermeneutics of Translation. Research in Phenomenology, 37(2), 147-159.

doi: https://doi.org/10.1163/156916407x185610

Key, J., \& Gillard, J. (2011, February 16). Joint Statement by Prime Ministers Key and Gillard: February 2011 Report on Trans-Tasman Cooperation. Press Release. Retrieved from https://www. beehive.govt.nz/release/joint-statement-prime-ministers-key-and-gillard-february-2011-reporttrans-tasman

Key, J., \& Rudd, K. (2009a, March 2). Key and Rudd - Joint Statement On Strengthened TransTasman Cooperation [The official website of the New Zealand Government]. Retrieved from https:// www.beehive.govt.nz/release/key-rudd-joint-statement-strengthened-trans-tasman-cooperation

Key, J., \& Rudd, K. (2009b, August 20). Joint Statement by Prime Ministers Rudd and Key [The official website of the New Zealand Government]. Retrieved from https://www.beehive.govt.nz/ release/trans-tasman-travel-become-faster-easier

Latour, B. (1987). Science in action. Cambridge: Harvard University Press.

Latour, B. (1999). On recalling ANT. The Sociological Review, 47(S1), 15-25. doi:10.1111/j.1467954X.1999.tb03480.x

Latour, B. (2007). Reassembling the Social: An Introduction to Actor-Network-Theory (New ed). Oxford, England: Oxford University Press.

Law, J. (1992). Notes on the theory of the actor-network: Ordering, strategy, and heterogeneity. Systemic Practice and Action Research, 5(4), 379-393. doi:10.1007/BF01059830

Law, J. (2000). On the Subject of the Object: Narrative, Technology, and Interpellation. Configurations, 8(1), 1-29. Retrieved from http://muse.jhu.edu/journals/configurations/v008/8.1law.html 
Law, J. (2007). Making a mess with method. In W. Outhwaite \& S. Turner (Eds.), The Sage Handbook of Social Science Methodology (pp. 595-606). Lancaster, UK: The Centre for Science Studies, Lancaster University.

Lindblom, C. E. (1959). The Science of "Muddling Through. Public Administration Review, 19(2), 7988.

Mallard, G., \& McGoey, L. (2018). Strategic ignorance and global governance: an ecumenical approach to epistemologies of global power. The British Journal of Sociology, 69(4), 884-909. https://doi.org/10.1111/1468-4446.12504

Marsh, D., \& McConnell, A. (2010a). Towards a Framework for Establishing Policy Success. Public Administration, 88(2), 564-583.

https://doi.org/10.1111/j.1467-9299.2009.01805.x

Marsh, D., \& McConnell, A. (2010b). Towards a Framework for Establishing Policy Success: A Reply to Bovens. Public Administration, 88(2), 586-587.

doi:10.1111/j.1467-9299.2009.01805.x

McConnell, A. (2010). Policy Success, Policy Failure and Grey Areas In-Between. Journal of Public Policy, 30(3), 345-362.

https://doi.org/10.1017/s0143814x10000152

McGoey, L. (2012). Strategic unknowns: towards a sociology of ignorance. Economy and Society, 41(1), 1-16.

https://doi.org/10.1080/03085147.2011.637330

Office of the Minister for Primary Industries, Office of the Minister of Immigration, \& Office of the Minister of Customs. (2012). Future Direction for the Border Sector (Cabinet paper No. Sub 12020). Wellington, NZ: New Zealand Government.

Ospina, S. M., \& Dodge, J. (2005). It's About Time: Catching Method Up to Meaning-The Usefulness of Narrative Inquiry in Public Administration Research. Public Administration Review, 65(2), 143-157. https://doi.org/10.1111/j.1540-6210.2005.00440.x

Rhodes, R. A. W. (2011). Thinking on: A Career in Public Administration. Public Administration, 89(1), 196-212.

https://doi.org/10.1111/j.1467-9299.2011.01898.x

Riley, M. (2003, September 23). Air travellers likely to pay bill for upgraded security. The Sydney Morning Herald , p. 5.

Roe, E. (1994). Narrative policy analysis. Durham, NC: Duke University Press.

Thiele, L. P. (2009). The Ontology of Action: Arendt and the Role of Narrative. Theory \& Event, 12(4). https://doi.org/10.1353/tae.0.0101

Unnamed journalist. (2009, August 20). Joint Press conference with New Zealand Prime Minister John Key [Official]. Retrieved from http://pmtranscripts.pmc.gov.au/release/transcript-16766

Van Assche, K., Beunen, R., \& Duineveld, M. (2012). Performing Success and Failure in Governance: Dutch Planning Experiences. Public Administration, 90(3), 567-581.

https://doi.org/10.1111/j.1467-9299.2011.01972.x

Van Hulst, M., \& Yanow, D. (2016). From policy "frames" to "framing": theorizing a more dynamic, political approach. American Review of Public Administration, 46(1), 92-112. https://doi.org/10.1177/0275074014533142 
Yanow, D. (2000). Conducting Interpretive Policy Analysis. Thousand Oaks, CA: SAGE Publications. Retrieved from http://srmo.sagepub.com/view/conducting-interpretive-policy-analysis/n6.xml

\section{Appendix}

\section{Dimensions of Policy Success}

\begin{tabular}{|c|c|c|}
\hline Dimensions & Indicators & Evidence \\
\hline \multirow[t]{4}{*}{ Process } & $\begin{array}{l}\text { Legitimacy in the formation of } \\
\text { choices: that is, produced through } \\
\text { due processes of constitutional and } \\
\text { quasi-constitutional procedures and } \\
\text { values of democracy, deliberation and } \\
\text { accountability }\end{array}$ & $\begin{array}{l}\text { Legislative records, executive min- } \\
\text { utes, absence of legal challenges, ab- } \\
\text { sence of procedural challenges (for } \\
\text { example, Ombudsman), absence of } \\
\text { significant criticism from stakehold- } \\
\text { ers }\end{array}$ \\
\hline & $\begin{array}{l}\text { Passage of legislation: was the legisla- } \\
\text { tion passed with no, or few, amend- } \\
\text { ments? }\end{array}$ & $\begin{array}{l}\text { Analysis of legislative process, using } \\
\text { legislative records, including identi- } \\
\text { fication of amendments and analysis } \\
\text { of legislative voting patterns }\end{array}$ \\
\hline & $\begin{array}{l}\text { Political sustainability: did the policy } \\
\text { have the support of a sufficient coali- } \\
\text { tion? }\end{array}$ & $\begin{array}{l}\text { Analysis of support from ministers, } \\
\text { stakeholders, especially interest } \\
\text { groups, media, public opinion }\end{array}$ \\
\hline & $\begin{array}{l}\text { Innovation and influence: was the } \\
\text { policy based on new ideas or policy } \\
\text { instruments, or did it involve the } \\
\text { adoption of policy from elsewhere } \\
\text { (policy transfer/diffusion)? }\end{array}$ & $\begin{array}{l}\text { Government statements and reports } \\
\text { (for example, White/Green Papers), } \\
\text { academic and practitioner confer- } \\
\text { ences, interest group reports, think } \\
\text { tank reports, media news and com- } \\
\text { mentary, identification of similarities } \\
\text { between legislation and that in other } \\
\text { jurisdictions identification of form } \\
\text { and content of cross-jurisdictional } \\
\text { meetings/visits by politicians and/or } \\
\text { public servants }\end{array}$ \\
\hline Programmatic & $\begin{array}{l}\text { Operational: was it implemented as } \\
\text { per objectives? }\end{array}$ & $\begin{array}{l}\text { Internal programme/policy evalua- } \\
\text { tion, external evaluation (for exam- } \\
\text { ple, legislative committee reports, } \\
\text { audit reports), review by stakehold- } \\
\text { ers, absence of critical reports in me- } \\
\text { dia (including professional journals) }\end{array}$ \\
\hline
\end{tabular}




\begin{tabular}{|l|l|l|}
\hline $\begin{array}{l}\text { Outcome: did it achieve the intended } \\
\text { outcomes? }\end{array}$ & $\begin{array}{l}\text { Internal programme/policy evalua- } \\
\text { tion, external evaluation (for exam- } \\
\text { ple, legislative committee reports, } \\
\text { audit reports), review by stakehold- } \\
\text { ers, absence of critical reports in me- } \\
\text { dia (including professional journals) }\end{array}$ \\
& $\begin{array}{l}\text { Resource: was it an efficient use of } \\
\text { resources? }\end{array}$ & $\begin{array}{l}\text { Internal efficiency evaluations, exter- } \\
\text { nal audit reports/assessments, ab- } \\
\text { sence of critical media reports }\end{array}$ \\
$\begin{array}{l}\text { Actor/interest: did the policy/ imple- } \\
\text { mentation benefit a particular class, } \\
\text { interest group, alliance, political } \\
\text { party, gender, race, religion, territo- } \\
\text { rial community, institution, ideology, } \\
\text { etc? }\end{array}$ & $\begin{array}{l}\text { Party political speeches and press } \\
\text { releases, legislative debates, legisla- } \\
\text { tive committee reports, ministerial } \\
\text { briefings, interest group and other } \\
\text { stakeholders'speeches/press releas- } \\
\text { es/reports, think tank reports, media } \\
\text { commentary }\end{array}$ \\
\hline Political & $\begin{array}{l}\text { Government popularity: is the pol- } \\
\text { icy politically popular? Did it help } \\
\text { government's re-election/election } \\
\text { chances? Did it help secure or boost } \\
\text { its credibility? }\end{array}$ & $\begin{array}{l}\text { Opinion polls, both in relation to par- } \\
\text { ticular policy and government popu- } \\
\text { larity, election results, media com- } \\
\text { mentary to each of these indicators. }\end{array}$ \\
\hline
\end{tabular}

Source : Marsh and McConnell, 2010 p.571 